\title{
Research on Historical Origin of Olympic Village
}

\author{
Xia Gao \\ School of Sports, Guangxi Normal University \\ No. 15 Yucai Road, Qixing District, Guilin 541004, Guangxi, China \\ E-mail: gaoxiasunny@hotmail.com \\ $\mathrm{Te} \mathrm{Bu}$ \\ Social Sports and Management, Tianjin University of Sport \\ Tianjin 300381, China \\ E-mail: buteagu@sina.com
}

Foundation Item: Initial Funding for Doctoral Research in Guangxi Normal University

\begin{abstract}
Honored as "heart" of Olympic Games, Olympic Village has its special status and value in the history of Olympic Games. After modern Olympic Games had passed for 36 years, the first Olympic Village with a groundbreaking meaning emerged in Los Angeles in 1932, which set up an ideal model for Olympic Villages in the future. Ever since Olympic Village was developed from its initial concept to an entity and was continuously developed and changed, Olympic Village gradually enriched the connotation of Olympism and was further interpretation of Olympic Value. The purpose of establishment of an Olympic Village was to construct an appropriate community space so as to spread friendship, stimulate communication and fulfill the eternal value of peace and progress pursued by Olympic Games.
\end{abstract}

Keywords: Olympia, Olympic City, Olympic Village

\section{Introduction}

Olympic Village is also termed as Contestant Village and Athlete Village. It is stipulated in the $39^{\text {th }}$ Regulation in the $5^{\text {th }}$ Article of "Olympic Charter", "In order to let all athletes, following officials and other working staff live together, the Organizing Committee for the Olympic Games has to provide an Olympic Village within a period of time stipulated by the International Organizing Committee Executive Board." Even in ancient Greece, athletes lived together in Olympia for training three weeks prior to the Olympic Games. Inspired and encouraged, these athletes were eager to defeat their opponents and wore the Olive Leave Laurel which symbolized victory and peace. The Olympic Village is not the residence place for athletes, but also carriers the ideal of Olympic Games and embodies the value of Olympic Games. A new residence relationship model is intended to develop in Olympic Village to enable athletes from different nations to benefit in interaction. So far, Olympic Village has already been the fundamental facility for the quadrennial Olympic Games and has been written into "Olympic Charter" established in an institutional form. Modern Olympic Village neither appeared by coincidence nor was changeless, and its development depends on particular historical and social background, undergoing a process.

\section{Historical background: City-state to City}

Ever since the beginning of the Industrial Revolution in the Eighteenth Century, under push of the tide of the Industrial Revolution, the society had been anticipated to stride towards the developmental direction that would stress human dignity, legalization, rationalization and liberalization. By the middle of the Nineteenth Century, quite a large number of ideologists were astonished by the cruel reality to see that what the industrial society had brought was a social nightmare, but not a beautiful scenery as forecasted. Coubertin also said, "The Nineteenth Century is a highly evolved century, but is also full of achievements caused by illusion. (Pierre de Coubertin, 2007)"

At the earlier Twentieth Century, what quite a lot of avant-couriers embraced was usually a sort of social responsibility who were devoted to an activity of "anti-industry devil (Dong Ming, 2005)". From a realistic perspective, a large majority of ideologists had a unanimous cognition in the realistic issue. That is, what they 
blamed for was the basic social values that was popular in industrial civilization.

Architects at that time became one of the avant-gardes of urban Utopianism and building became one of the edge tools to modify disadvantages in cities. Architects intended to re-construct the society through architectural and spatial operation. They wished to reform the industrialized society with morality and knowledge and make urban citizens, especially the proletariats, become affluent, bourgeois, stable, community and garden city residents.

Deeply encouraged and enlightened by Thomas Arnold at that time, Coubertin believed, sports activities organized according to definite rules were beneficial to young people and the whole human being, not only good for physical quality, but especially conducive to improve moral standard. At the same time, profoundly affected by the French Social Reformer Frederic Le Play (1860-1882), Coubertin had a strong social responsibility for the extensive public, especially the proletariat (Pierre de Coubertin, 2007). Without doubt, his idea was unanimous with that of sociologists with the thought of reform at that time, except that the idea of Coubertin took sports as the carrier, while sociologists, including architects with positive thinking, expressed their feelings through cities and buildings.

No matter what was the attitude of avant-courier ideologists towards the industrialized society, their ideal was usually an ideal design about the society in the future. Whatever they might embrace different emotional feelings and hold different perspectives for analysis of problems, it could not be denied that the career they had initiated was a great social event. They believed that their theoretical foundation was correct and their prospect was bright.

From the perspective of etymology, city-state and city have similar sources of root. In Latin, Civilization and Urbanization are synonyms. According to OswaldSpengler, "All great cultures of human kind are evolved from city. The history of the world is the times history city in human kind. Nation, government, politics and religion, etc, have all been evolved from the basic form of human existence (city) and are attached to the city. (R.E. Parker et al, 1987)" In ancient Greece, city-state later became "focus of the morality, rationality, aesthetics, society and practical life of human being, which was developed and enriched in this form, which there was not any social pattern before and after this form that could be compared with. (H.D.F. Kitto, 1998)"

Olympic Village is an entity, with its own particularity, and is termed as "a miniature city" (Los Angeles Organizing Committee, 1985:235), "a city within cities". Thus, it can be seen that people have endowed Olympic Village a beautiful ideal and significant value.

City is the center of modern civilization of human kind, in which plenty of goods, service and ideas are produced and disseminated and the most intimate interpersonal relationship is also produced. Since city helps to reduce spatial distance and obstacle, people can come into contact with the most abundant human culture here. "There is no reason to presuppose that Olympia was set up in any desert that is far from supply of electric power, water and light. (Pierre de Coubertin, 1993)" Hence, city sets up a stage for modern Olympic Games.

\section{Historical Evolution: Olympic City to Earlier Olympic Village}

\subsection{International City and Olympic City}

A general embracement of the thought of peace and globalism is exactly the general thinking of European intellectuals in the Twentieth Century (Leften Stavros Stavrianos, 2005). After 1899 when after Hague Peace Conference was held, Hague became a permanent headquarter for peace conferences. Inspirited, the famous architect Emest Hebrard put forward to idea of "International City" in 1910. The International City he defined was "a city that is of the greatest importance and where all activities about peace have to be held (Francesc Munoz, 1996)". In Hague, the intellectuals could converge together to resolve any conflict that might have been caused by new partition of the world among influential powers in the world, so as to realize the will of peace. His idea had great influences upon the intellectual circle of Europe at that time.

Deeply inspired and embracing with the same will, Coubertin wished that the International Olympic Committee could also have a permanent headquarter. "We should not forget....., the International Olympic Committee has always been depending on others for living and also says to others, 'How beautiful your living room! Could you please spare your field of fortune for us to have a get-together? That would be a magnificent and brilliant event!'”. (Pierre de Coubertin, 1993) On April 10, 1915, the permanent headquarter of the International Olympic Committee was finally formally established in Lausanne. Therefore, joy of Coubertin was shown in facial expressions, "We have had the mind ever since 1907 to turn Switzerland into the international event center. In 1913, the Olympic Congress called for all friends from the sports field to get together in Lausanne --- the Olympic City, where the goal of peace and glory the International Olympic Committee had advocated and strived for would continue to flourish and where people would breathe guarantee of the Olympic Games to 
freedom at an independent and self-esteem atmosphere. Thus, they would further long for freedom(Pierre de Coubertin, 2007)" Here, the Olympic City refers to Lausanne (Note 2).

The concept of the Olympic City proposed by Coubertin had amazing similarity with the concept of the "international city" put forward by the architect Emest Hebrard at the same era. Both of the two concepts take peace as the starting point. Thus, some people say that, if Emest Hebrard was hailed as the master of the idea of peace, then Coubertin should be honored as the master of peace and sports (Francesc Munoz, 1996).

\subsection{Modern Olympia and Olympic Village}

The first one who put forward the concept of "Olympic Village" was also Coubertin. Deeply influenced by the ancient Greek civilization, Coubertin believed that ancient Olympia was a city of athletics, arts and prayer. The sacred and aesthetic quality of Olympia was the outcome of its body-building. As an athletics city, Olympia was intermittent, whereas it was perpetual as a city of arts and prayer. He thought, "There was nothing in the history of ancient Greece that had touched me more than Olympia. Olympia was an ideal city... sanctity and fascinating (Pierre de Coubertin, 1993)."

In August 1910 when the Paris international architectural arts competition was held, Coubertin made a speech with the topic of "A Modern Olympia" in face of architects. He summoned the architects with enthusiasm, "It is now the right time for architects to fulfill the great dream and to use their own wisdom to create a glorious and brilliant Olympia; here, we not only have innovation of modernism, but have solemnness of traditionalism (Pierre de Coubertin, 1993)."

Coubertin assumed, "The same is true to modern Olympia and it will always exist for holding the Olympic Games. Olympic City has to be immerged in a solemn atmosphere, neither too serious, nor required to get rid of happiness. Thus, at the interval of the competition, Olympic City will attract visitors just as the pilgrimage. Furthermore, it will gain their respect since it is an occasion which brings sweet memory and strong will (Pierre de Coubertin, 1993)." Here, Olympic City does not specially refer to Lausanne, but refers to the host city that holds the Olympic Games.

In addition to the competition terrain, Coubertin also took into consideration of hotels and the problem to resolve accommodation for contestants. He imagined, "We might open a camp or a military camp nearby the competition terrain to provide housing for athletes during the competition" (Pierre de Coubertin, 1910). Olympic Village had to be a centralized place, where all young people all over the world could get together to promote mutual understanding. This is the initial envision of Coubertin about the concept of the Olympic Village which can be regarded as the initial blueprint of the Olympic Village. During the first 20 years of the Twentieth Century when development of the Olympic Games was not determined, let alone the planning of the Olympic Village, the design was mostly caused by realistic issues, and its resolution project was to resolve the realistic problem of athletes, namely, accommodation. The host country of the Olymic Games wished to express the pursuit for the ideal of the Olympia and its own cultural traditional through the Olympic Village. However, there was no way at that time to talk about presentation of the magic of the city, etc.

\subsection{Earlier Development of Olympic Village}

During the first ten years of the Twentieth Century when the Olympic Games just came into being, its development was at an unstable and undetermined exploratory stage. Relative to the problem of accommodation, there were a lot of more urgent problems that called for more attention and resolution, such as, definition of amateur athletes, competition rule and options of the Olympic Games, etc. In addition, some cities at that time still maintained the structure of former industrialization, and cities of former industrialization were still cities of small scale "walking (Paul Knox \& Steven Pinch, 2005)". Thus, at the first several Olympic Congresses, the problem of accommodation was not an outstanding one, and would not become the primary topic for discussion. During that period of time, consideration of the organizing committee of all participating countries was mostly generated by realistic issues, nothing but arrangement for the place of accommodation. The International Olympic Committee by that time had not had a mature idea about construction of the Olympic Village, but just thought of an expediency in particular cities under particular conditions. The planning and controlling of construction of the Olympic Village, its concentricity and dispersiveness, long term and short term and comprehensiveness and singleness, etc., had no way to be taken into account. Today, Olympic Games is part of the organism of Olympia, and the Olympic Village at that time still lagged behind from whichever aspect. The idea of construction and design of the Olympic Village was ambiguous, undefined and fragmentary. This situation had not been changed until 1932 when the Olympic Games was held in Los Angeles.

The number of athletes who took part in the Olympic Games at that time was limited, which was also an actual 
reason that affected the project of accommodation, which is shown as in Table 1.

\section{Insert Table 1 Here}

At the earlier period of development of Olympic Games, the International Olympic Committee was faced up with quite a lot of difficulties, and the organizing committees of all participating countries were also beset with difficulties. The Organizing Committee of the International Olympic Games was encountered with undetermined difficulties and the number of participants could not be confirmed, especially those delegations with a small number of athletes. And even there was no way to make clear the time limit for accommodation of athletes.

All participating countries were also faced up with difficulties in insufficient funding for athletes, which caused travelling expenses, accommodation expenses and living expenses to become obstacles for the competition. With an increase of the number of athletes, participation in the competition by more and more athletes became a burden for the participating countries. Hence, the participating countries began to negotiate with the host country to resolve the problem of accommodation.

Hotels, of course, were the necessary choice and were also faced up with difficulties during competition. With regard to this, the Organizing Committee of the Olympic Games had to negotiate with hotels to divide hotels into different classes and for a special offer, giving priority to tourists during the Olympic Games. However, the number of tourists during the competition was also hard to confirm. This uncertainty incurred complaints of the hotel industry. The Organizing Committee of the Olympic Games had to set up management organizations to take into account the issue of living in hotels by tourists. In the mean while, the Organizing Committee also gradually came to realize that there hadn't been enough hotels to resolve the problem of accommodation of a large number of tourists. Then, the committee conducted a survey research on the host cities with a view to discover any place that could be temporarily used for accommodation, such as, school, army and red cross society, etc. (Bergvall, Rik).

In 1896 when the Olympic Games of Athens was held, the issue of accommodation did not arouse enough attention since the number of athletes was small. And the proportion of female athletes was throughout smaller, so it didn't get enough focus. Even in 1932 when the first Olympic Village appeared in the Olympic Games of Los Angeles, female athletes were not considered to live in the Olympic Games out of the consideration of "security" (Al Stump, 1932).

In 1908, athletes of the Olympic Games of London rapidly increased to more than two thousand. Thus, the Olympic Committee of London set up a center to take responsibility for investigation of the housing situation and to resort to hotels and residents with the purpose of offering comfortable accommodation conditions for athletes and their chaperonage. However, during the two weeks' competition at that time, sports delegations of most countries didn't live fully.

In 1912, the Olympic Committee of Stockholm set up "Accommodation Committee of the Olympic Games" and "Housing Committee", and respectively arranged delegations from different countries in schools and hotels, furnished different facilities and charged according to different accommodation conditions. The Organizing Committee of this Olympic Games delivered free of charge for participation athletes sports equipment and horses for horse racing and gave a discount of $50 \%$ for the railway charge of athletes and officials (Bergvall, 1913:26 and Verdych,1920:14). What deserves to be mentioned, during that Olympic Games, Sweden provided houses for its own athletes nearby the gymnasium and furnished housing and meals from one month prior to the Olympic Games until the end of the game, but only athletes of Sweden could eat and live there. Thus, it could not be counted as an Olympic Village in its real sense.

In 1920 when the Olympic Games of Antwerp was held, "Accommodation office" was set up. During this Olympic Games, schools, army and red cross societies offered critical assistance and provided bedding and mattress and cooking utensils. The Organizing Committee of the Olympic Games took local schools as temporary accommodation place of the Olympic Games.

In 1923 when the Roman Assembly was held, the Executive Board of International Olympic Committee made clear the concept of accommodation of the Olympic Games, and stated the concept as "the Organizing Committee of the Olympic Games has to furnish housing and all necessary services for athletes. A contract has to be formed and charges have to be fixed each time. Expenses required have to be assumed by the participating nations themselves." In 1924 when the Olympic Games of Paris was held, the military camp in the open space nearby the gymnasium of Colombes offered collective housing for athletes, including wood houses, each house equipped with three beds, two face washing pools, tap water and shower. This was the first attempt to provide collective accommodation for athletes. However, in whichever way, use of military camp in Paris was identical 
with imagination of Coubertin of the Olympic Village.

Four years later during the Olympic Games of Amsterdam, an open dispute was conducted as to how to resolve the problem of accommodation. The Organizing Committee of the Olympic Games at that time considered constructing an Olympic village, but they finally gave it up because they could not set up a convenient building facility at a "rational price (Netherlands Olympic Committee, 1930:227).

Then, the idea of collective housing was set aside. Thus, the "Apartment Department" of the Amsterdam Organizing Committee made a survey in the downtown and found that there were two thousand beds in the existing hotels. However, by reference of the last Paris Olympic Games, it was estimated to require 5 thousand beds. The Organizing Committee visited the industrial fair in Leipzig and Colombes. However, they had no means to predict the number of tourists and arrange accommodation according to previous situation. Finally, the Organizing Committee decided not only to arrange accommodation in the downtown of Amsterdam, but would take into consideration of suburbs within the sphere of 60 kilometers nearby, altogether including 48 hotels among which 20 were located in the downtown of Amsterdam, and 28 were located in suburbs, 12 hotels were high standard hotels and 9 hotels were located in the downtown of Amsterdam. Besides, the municipality authority also offered eight schools and rented 18 ships to stop at the port. For example, US athletes were arranged at the "President" ship, and Italian athletes were arranged at the "Solunto" ship. Thus, the accommodation problem was almost resolved. However, athletes complained that they "could hardly bear" by living in ships (Dagoberto Ortensi)".

\section{Historical Innovation: Birth of the Olympic Village}

The historical background for this Olympic Games could be said to be back against the wall. In 1929, the US stock market crashed, and then happened employment on a large scale. By the year 1930, there had already been over 700 thousand people out of work merely in California. There were 350 thousand people out of work in Los Angeles and the adjacent Oregon. Only in the film industry in Los Angeles, there were 35 thousand people who were out of work, and the same was true to the aircraft industry and the oil industry (Stump, 1990:383). In Broadway and Spring, etc, mobile kitchens for relieving impoverished people offered foods free of charge to despaired people, and these mobile kitchens were located in the street blocks within the eye reach of the magnificent Memorial Coliseum (the sports ground of this Olympic Games). In Southern California, working opportunities were declined, such as in the retail industry, in aircraft industry, well drilling industry and the film industry, etc. One of the songs that were popular at that time was "Brother, Can You Spare A Dime?"

In 1930 when the Berlin Conference was held, the International Olympic Committee proposed two resolutions as for accommodation of athletes: use of the Olympic Village and use of City Hotel. Since Los Angeles had a limited number of hotels, their expense was quite expensive. The Los Angeles Organizing Committee Secretary Zack Farmer had to propose his qualified opinions for this, and the two parties didn't finally reach a consensus. This situation became more awkward with the approaching of the Olympic Games two years later with a huge expense. Opponents hung small flags everywhere to express their opposition to the Olympic Games. "Why we have to pay for playing since we are so poor?" That was their reason.

James Rolpph, Governor of California, called off the $10^{\text {th }}$ Olympic Games under enormous pressure. He sighed, "It seems that the Olympic Games is impossible... We might have a disturbance." Traditionally speaking, the head of the host country had to take part in the opening ceremony. However, the American President, Herbert Hoover, refused to take part in the opening ceremony. He thought, "Olympic Games is a mistake --- now." Los Angeles came under fire everywhere and was thought to be unfair and would lead to a bankruptcy of all cities in the entire country. All countries in Europe and South America were also in an economic difficulty, and they doubted whether they had the competence and financial power to take part in the competition. Brundage predicted that there would only a small number of people who would come to this catastrophic land.

William May Gardland was the actual leader and the real builder of this Olympic Games (Note 3). At the most critical moment, Gardland and Farmer, for the first time (Gresleri G.), proposed an extraordinary innovative idea, "To specially build a 'common village' for all participating athletes". (Gresleri G.) At this time, the concept of Olympic Village was put forward. Collective accommodation and eating might save quite a lot of money. However, was this practice that violated the tradition feasible? "It does not mean living apart and dining apart", said Farmer, "Why people from different nations could not live together just like neighbours?" In a voice of opposition, and on the Baldwin Hills (the sports ground of the Olympic Games) that overlooked Los Angeles, a miniature city that occupied an area of 250 acres was set up, namely, "village of the universe". In addition, with a view to the situation of difficult economy, this Organizing Committee also provided the following preferential terms which was difficult to resist: resolution of accommodation, mobilizing local transportation, a discount of 
$20 \%$ for steam ships that crossed the Atlantic, a discount of $40 \%$ for the railway and an expense of only two dollars each day. The railway sold the round-trip tickets from New York to Los Angeles at a price of only 100 USD, and the price of the ticket that had the largest distance was 500 USD, which was supposed to be 2000 USD in regular period of time. Some sports teams in some countries, such as Cuba and Brazil, even took sugar, tobacco and coffee on the ship. In such way, they could sell out these goods for travel expenses when their ships were pulled into the shore (Stump, 1990:380 and 385).

Those European Countries that had previously thought tourism and accommodation were too expensive then were attracted by the concept of Olympic Village. In Olympic Villages, it only took one athlete two dollars each day to resolve the problem of eating and housing.

The Olympic Village with almost 550 "Olympic cottages (Gresleri G.)" which was decorated by 30,000 blooming plants becomes a beautiful place. There were approximately 2 thousand athletes and officials residing there. The Olympic Village was regarded as the perfect place in the Olympic Games.

The Olympic Village included restaurants, sauna bathrooms, Greek Theaters, barbershops, post offices, and even attendants. All the following facilities made it convenient for everyone: pure woolen carpet, thick towels particular for athletes, reading tables, hot shower, bottled distilled water and telephone. There was even Steam Sauna, meticulously decorated kitchen offered specially for athletes from the Scandinavia Peninsula countries. In the kitchen, 23 chefs, 16 assistant chefs and 130 assistants who provided local foods for athletes.

Famous stars from Hollywood also came to the numerous athletes and lived together with them in the Olympic Village. These famous stars included Charlie Chaplin, Weissmuller who had acted the leading role in "Tarzan", the hot property Marlene Dietrich, etc, from Hollywood, and there were also a large number of stars. Those athletes who came from foreign countries and had not had an opportunity to witness actual American West cowboys were entertained there and they watched the excellent performance by men in luxuriant clothes.

There, difference of classes disappeared thoroughly. 23 noble-blood athletes ate and lived together with bricklayers, merchants and farmers who came from the parliament, the royal court and had the title of nobility. This kind of living mode was exactly the ideal of Coubertin, that is, without difference, without hierarchical isolation and without any conflict. The most intimate living relationship became realistic there. The administrative organization of the Olympic Village was operated so perfectly that the Organizing Committee of this Olympic Games won the nomination of the award of Nobel Peace Prize.

In 1932, Los Angeles made it possible to live together in the Olympic Village with a modern method and set up the "value model (Francesc Munoz, 1996)" for Olympic Games. This Olympic Village not only had offered appropriate rest place for athletes, but was a social intercourse center of friendship and communication. The concept of (Olympic) Village was believed to be one of the most successful outcomes in the Olympic Games in 1932 and it became a brand-new thing in the history of the Olympic Games. In view of this, the International Olympic Committee determined that, any host country in the future had to construct an Olympic Village to provide accommodation for athletes. From then on, "Olympic Village" was formally written into "Olympic Charter" and was confirmed and guaranteed in an institutional form.

The Olympic Village is a building in which athletes reside, and the building is the space in which human being live, because the ultimate goal for a building activity is to "help people find out their base area of existence and apprehend its implication (Kevin Lynch, 1982)" just as what Soultz said. If the Olympic competition terrain is a competitive stage to convey the idea of "swifter, higher and stronger", then the Olympic Village is the best space to expound the ideal of Olympic Games. Here in the Olympic Villages, "what is important is not to gain victory, but to take participate", where athletes share their friendship and promote understanding.

Here, as a new building, we can get a best explanation for Olympic Village by referring to sighing of Rowe, Colin, "A new building is determined by rationality and laid foundation by the history. A new building represents overcoming the history and stands for the spirit of the era. A new building is the effective medicine to cure the society and a new building is young and self-updating. It will never lag behind the era (Li Shaolin, 2006)".

\section{Conclusion}

The first Olympic Village in the history appeared. Although its appearance was 36 years later after the opening ceremony of the first Olympic Games, its significance can't be ignored in terms of its innovation. Its appearance provided the model for construction of Olympic Villages in the future. So far, the Olympic Village has been integrated into the organism of modern Olympic Games and the physical structure and functions of Olympic Village have begun to be taken into consideration and enriched day by day, and it has been developed into a miniature city. Furthermore, the Olympic Village has been integrated into the host cities and become the 
organism of the host city. The Olympic Village has had its rational design. Study on the subject of the Olympic Village from different perspectives, different professional experiences and different historical backgrounds is not only helpful for development of athletes and the Olympic Games, but benefits a lot to host cities of the Olympic Games in the future and any host cities of important sports events.

It is believed, whether in winter or in summer, the Olympic Village ought to be constructed as a model that has no obstacle, has permanent developmental competence and respects environment and life quality in the modernized cities.

\section{References}

Al Stump. (1932). The Hopeless Dream of William May Garland. [Online] Available: http://web.ebscohost. Com.

Bergvall, Rik. The official report of the Olympic Games of Stockholm. [Online] Available: http://www.aafla.com.

Dagoberto Ortensi. The Olympic villages and the gigantism of the Games. [Online] Available: http://www.athens2004.com

Dong, Ming. (2005). Urban Planning from an Urban Perspective. Beijing: China Architecture \& Building Press.

Francesc Munoz. (1996). History evolution and urban planning typology of Olympic Villages. Olympic Villages: A Hundred Years of Urban Planning and Share Experiences International Symposium on Olympic Villages, Lausanne.

Gresleri G. Urban Development and Olympic. Olympic Review, 34 -35.

H.D.F. Kitto. (1998). The Greeks, translated by Xu, Weixiang, et al. Shanghai: Shanghai People's Publishing House.

Kevin Lynch. (1982). A Theory of Good City Form. MIT Press.

Leften Stavros Stavrianos. (2005). A Global History: From Prehistory to the $21^{\text {st }}$ Century. Beijing: Peking University Press.

Li, Shaolin. (2006). History of Western Architecture. Hohhot: Inner Mongolia People's Publishing House.

May, 1930-afternoon.Bernlin congress. IOC [Online] Available: http:// www. aafla.com.

Paul Knox \& Steven Pinch. (2005). Urban social geography. Beijing: The Commercial Press.

Pierre de Coubertin. (1993). Olympic Ideal --- Selected Works of Coubertin, translated by Zhan, Rucong and Xing, Qizhi, et al. Beijing: Olympic Press.

Pierre de Coubertin. (2007). Olympic Memoirs, translated by Liu, Hanquan. Beijing: Journal of Beijing Sport University.

R.E. Parker et al. (1987). Urban Sociology, translated by Song, Junling, et al. Beijing: Hua Xia Press.

\section{Notes}

Note 1. This phrase originated from ancient Greece, and it refers to those city-states that dreamed of becoming the object admired by all civilizations.

Note 2. In the history, a host country of the Olympic Games was termed as Olympic City. As a matter of fact, Lausanne in Switzerland was the only Olympic City that did not hold the Olympic Games. In "Olympic Charter" in 1991, it said, "The headquarter of the International Olympic Committee was set up in Lausanne (Switzerland)". In 1982, the International Olympic Committee announced Lausanne as the "Olympic City". On December 5, 1993, the International Olympic Committee again announced Lausanne as the "Olympic Capital". Switzerland divided perpetual land to the International Olympic Committee as its headquarter.

Note 3. During the first ten years of the Twentieth Century, people in California called him "an unyielding leader". Gardland was born in a noble family, including 30 industrialists, pioneers in the oil field, developers in the tourism and Louis B. May --- the tycoon in the film industry, et al (Stump,1983:375). 
Table 1. Condition of growth of the Olympic Games from 1896 to 1932

\begin{tabular}{|lllll|l|}
\hline Yea & Place & $\begin{array}{l}\text { Participating } \\
\text { country }\end{array}$ & Male athletes & $\begin{array}{c}\text { Female } \\
\text { athletes }\end{array}$ & $\begin{array}{l}\text { Total number of } \\
\text { athletes }\end{array}$ \\
\hline 1896 & Athens & 13 & 311 & 0 & 311 \\
1900 & Paris & 22 & 1319 & 11 & 1330 \\
1904 & Saint Louis & 12 & 681 & 6 & 687 \\
1908 & London & 23 & 1999 & 36 & 2035 \\
1912 & Stockholm & 28 & 2490 & 57 & 2547 \\
1916 & Cancelled (due to the WWI, & & & 2606 \\
1920 & Aniginally in Berlin) & 29 & 2542 & 64 & 3092 \\
1924 & Paris & 44 & 2956 & 136 & 3014 \\
1928 & Amsterdam & 46 & 2724 & 290 & 1408 \\
1932 & Los Angeles & 47 & 1281 & 127 & \\
\hline
\end{tabular}

Source of data: http://www.olympic.org/uk/games/past 